\title{
Identifying the Key Factors Influencing Technology Management in the Power Plant and Electric Power Industry, and Prioritizing Factors Using Network Analytical Process (ANP): Evidence from MAPNA Group
}

abbas khamseh ( $\square$ abbas.khamseh@kiau.ac.ir)

Azad University: Islamic Azad University

maryam kheradranjbar

Islamic Azad University

Research Article

Keywords: Technology, Technology Management, MAPNA Group, Power Plant and Electric Power Industry, Network Analytical Process (ANP)

Posted Date: December 3rd, 2021

DOI: https://doi.org/10.21203/rs.3.rs-1099138/v1

License: (c) (1) This work is licensed under a Creative Commons Attribution 4.0 International License. Read Full License 


\section{Abstract}

This research has been conducted in order to identify and determine the order of influential factors on technology management in MAPNA Group. After studying the related literature and collecting conducted researches and experts' opinions, 71 influential indicators were identified in the technology management of power plants and the electric power industry. Afterward, the opinions of experts in the industry and university concerning the influence of these factors were collected by designing a questionnaire and using Likert scaling, and next, decisions were made regarding these indicators. After this process, 51 indicators were approved and categorized into 6 factors and 12 dimensions, based on which the final questionnaire was designed and distributed among 32 managers and experts of MAPNA Group. Using structural equations and Smart PLS software, the research model was fitted and ultimately, surface six indicators were approved for the designed model. Also, the ANP technique was utilized in order to determine the order of factors and the result illustrated that factors namely "propagation" and "acquisition" were given the 1st and 2nd order respectively and factor "protection" was given the last order. According to the conducted researches in the technology management of MAPNA Group, all six facts factors have a significant influence on technology management and hence, all six factors must be paid attention to. In case such a thing does not happen, reaching success in technology management will fail.

\section{Introduction}

One of today's concerns of organization managers is to improve business performance and reach high profit margin. In this vein, managers are putting their effort into finding influential factors on the performance of their organization and determining the most crucial and influential factors that will guarantee the survival of their organization in the future [25].

The concept of technology management was developed in 1980. Technology management is a system that simplifies the creation, acquisition, and use of technology, and it includes certain exclusive liabilities that are guiding the activities to serve the men and realize humankind's needs. Among the most important matters/problems that resulted in the advancement of technology management ways, the following items can be named: research, invention, development, etc. This type of management is highly inclusive and consists of all technological dimensions, namely policy making, planning, transferring, developing technology, R\&D, education, selection, and evaluation [6].

Technology management can be a great help to the stable competitive advantage. This matter can be explained by the fact that creating and preserving competitive advantage relies highly on minimized expenses, more than operational effectiveness. Related to high technology corporations, creating competitive advantages is highly associated with the capability to manage technology assets [16].

Technology management will help adjust the changing conditions of the environment and technological development, and the creation of these changes. It is also considered a challenger in order to promote 
existing technologies and generate new knowledge and skill in response to today's competitive business environment. From the viewpoint of the "National Research Council", technology management is an interdisciplinary field for planning, developing, and implementing technological improvements in order to form and realize the strategic and operational objectives of an organization.

Hence, the objective of this research is to identify and determine the order of influential factors on the technology management of MAPNA Group and there has been no research conducted associated with power plants and the electric power industry. Therefore, this research is highly innovative.

\section{Literature Review}

Complexity, connection, and increased speed of technological developments are considered large challenges for technology-intensive organizations that intensified the necessity of focusing on technology management activities to effectively respond to performance-related problems. Therefore, a fully structured and understandable technology management process will be viable in order to guarantee the constant and efficient allocation of resources that will be a help in the firm's success and preserving its place in the competition arena. Therefore, being aware of the cause and effect relationship between performance and activities of technology management, followed by technological developments and the effects of designing and evaluating efficient technology management is highly viable and important for an organization [2].

Technology management seeks to reach high efficiency and also help the organization act in an efficient manner in order to the desired objectives. Hence, technology management addresses this matter "the potential to compete in the developing work market", to guarantee survival. Acquisition of competitive advantage is a process by which a firm will attempt to dominate the other. Technology management should be able to guarantee the firm's competitiveness/firms power to compete. In local, regional, and global markets, the competitive advantage of firms will be guaranteed by producing or providing products and services at competitive prices and using agile methods [18].

Due to the technological changes in both products and processes, technology management is one of the most important operational programs, management of which is necessary for business success. This work includes hardware systems and human and organizational aspects [5].

According to "National Research Council", technology management is a process consisting of planning, guiding, controlling, coordinating, developing, and implementing technological capabilities in order to shape and accomplish the strategic objectives of an organization. Educating technology management is significantly important in order to solve problems in organizations [24].

At the national level, technology management consists of subjects such as the influence of technological developments on people, their educational needs associated with technology, the effect of technology on health and security, and environmental consequences of technology. At the governmental and 
organizational level, technology policies are in fact a framework in order to use technological changes for the benefit of society and organizational staff [17].

Technology management is defined as a process that enables the company by managing all the activities to utilize domestic and outsourced technologies, combine the new products (innovation in the product), methods used to produce them (innovation in the process), and deliver them to the market efficiently [11].

Technology management is about managing selection, acquisition, utilization (exploitation), development (improvement), and promotion of technologies [19]. Since this field of technology management is new, the tools of this branch own exclusive features. Most of the utilized tools in this field are inspired by the tools used in other fields. Schumpeter (1928), known German economist, believed that creativity in competitive capitalism emerges exclusively in the structure of new firms. In other words, creativity occurs in competitive capitalism as the number of industrial families increases. Schumpeter believed that the profit of entrepreneurs is the main source of industrial development and success, and according to the innovative entrepreneurs, the process of creativity in the industry is the key to all phenomena that will lead to value and wealth creation. All the entrepreneurial activities are passing through the channel of innovative development and technology management.

Esco \& Cramer (2016) studied technology management by reviewing the variables of management activities, the strategic objectives, numerous control tools for evaluation, and monitoring in technology management. Moreover, Cheong (2016) reviewed the competition of domestic companies in the global semiconductor market by studying the variables of global competition, efficient strategies, investment, and market. Schoan et al. (2016) conducted a conceptual review of appropriate support and model for identifying and evaluating the production technologies. Fall \& Setindemar (2016) studied the current and future managers in the field of technology management by studying innovation, exploitation, and strategy variables. Lois Vinchi (2016) reviewed the management of mental health support networks. Ketonen et al. (2015) reviewed the flexible relationship of developing new technologies in competitive settings. By studying the variables of new management technologies principle four exchange, R\&D, development, design, engineering, and production, Amasak (2015) re-evaluated the path of management technologies in the new JIT manufacturing industry, and original new technology management. Yan \& Variu (2015) study the role of technology management in reviewing and focusing on annual energy saving. Sieryamakin ha (2014) reviewed the use of advanced technology management in order to educate the personnel. Moreover, Peng Yu \& Jong Hey Ley (2013) reviewed the technology and how to properly choose it by studying the variables of investment and technology. Park \& Goori (2011) reviewed the distinction between managerial and technological knowledge and the significance of business communication.

Eslami \& Nategh (2016) reviewed the impact of the connection between technology management and comprehensive quality management on innovation performance and quality. Var \& Hammati (2016) reviewed the influence of variables "system engineering" and "knowledge management" on technology 
management. Hosseinian \& Adamiyat (2016) studied the process of technology management and the influence of variables, namely "IT", "process and necessities of technology management", and "technology strategy". Feizabadi et al. (2015) reviewed the evolution of technology by studying the variables "technology" and "strategic methods". Ekhtiary et al. Compare technology management in Iran and Singapore, where variables, such as education, society, information networks, and dynamic settings are reviewed. Khoshbini and Eskoi (2015) reviewed the impact of indicators, namely technology management, development of human resources, and level of access to natural resources, on economic growth.

Sanjei et al. (2019) conducted a research titled "The value of superior management knowledge and knowledge sharing, open innovation, on organizational performance". Statistical population of this study includes small and medium-sized firms in the United Arab Emirates that 404 firms were chosen as the sample. The structural equation modelling was utilized in order to test hypotheses. The findings of this study illustrated that value of superior management knowledge and knowledge sharing methods have an impact on open innovation that will in turn influence organization performance [21].

Horri et al. (2018) conducted a research titled "The relationship between technology management and operational performance in gas measurement tools (gauge) manufacturing companies". The objective of this research is to identify indicators and review the relationship between technology management and operational performance, and also to review the role of technology management in gaining competitive advantage, as the most important resource for performance prediction. After conducting the data analysis, research findings illustrated that technology management has the capability to predict the operational performance of a company. In other words, improving technology management will lead to better and higher operational performance. Indicators of operational performance in this research are as follows: performance, efficiency, quality, and innovation [14].

Ghahremani (1396) investigated the effect of technology management and R\&D management on organizational performance in terms of quality and innovation and in the companies with more than 300 participants from the Ardebil and East Azerbaijan provinces. This research is a descriptive study in which the role of technology management and R\&D management was tested in order to predict organizational performance with regard to quality and innovation. Indicators namely quality and innovation are the most important sources for organizations to gain competitive advantage and they were analyzed using structural equations modeling. Findings of this research show that technology management, R\&D, and development are capable of anticipating the qualitative performances of an organization but they are more capable of anticipating the innovative performances of the organization [10].

Ansari et al. (2016) conducted a research in order to review the influence of technology management activities on the agility capabilities of an organization (a case study of Yazd Rolling Mill Co.) where descriptive statistics, inferential statistics, and structural equations modeling were utilized. The objective of this research is to review the effect of technology management activities on the agility capabilities of an organization. The research model was inspired by the previous literature and shows that technology 
management activities include six activities, namely acquisition, identification, utilization, education, protection, and selection. Moreover, agility capabilities include four components as follows: fitness, accountability, flexibility, and speed. According to data analysis, all six activities affect the agility capabilities of the organization under this study directly [4].

Arana et al. (2018) conducted a research in which they reviewed the contextual factors influencing the relationship between strategic management, technology management, and performance and the research is associated with 14 countries and 241 companies in two fields of electronics and machine manufacturing. One of the objectives of this research is to respond to these questions: "Do strategic management and technology management improve operational performance?" and "Do contextual variables influence the operational performance?". According to the hierarchical regression analysis, technology management can positively affect operational performance [5].

According to the previous literature presented in this section, the research methodology has been explained as follows in order to theoretically support the research subject.

\section{Methodology}

Since this research is systematically explaining the current condition, the research is a descriptive study. Moreover, it is a field study due to the direct connection of the researcher with phenomena under the study and it is considered applied research since factors influencing technology management in the electric power industry are identified and evaluated, and then used in the same industry. Ultimately, this research is a case study since it is conducted in MAPNA Group. Due to the limited statistical population that can answer the research questionnaire, sampling was (done) in a full-census manner. By using a questionnaire and conducting interviews with experts, the data were gathered. Cronbach's alpha was utilized in order to evaluate the reliability of the questionnaire? Cronbach's alpha is opting to be 0.821 using SPSS software, which illustrates that there is an internal correlation between the questions and as a result, the existence of homogeneous questions. The questionnaire's reliability was approved according to the judgment of experts.

After studying the related literature and collecting conducted researches and experts' opinions, 71 influential indicators were identified in the technology management of power plants and the electric power industry. Afterward, the opinions of experts in the industry and university concerning the influence of these factors were collected, and then decisions were made concerning these indicators. After screening, 51 indicators were approved and categorized into 6 factors and 12 dimensions. The main identified dimensions are as follows: utilization, acquisition, protection, identification, selection, propagation, development, and improvement. Based on these dimensions, the final questionnaire was designed and distributed among 32 managers and experts of MAPNA Group and then, the results were collected. Using structural equations and Smart PLS software, the research model was fitted, and ultimately, the order of influential factors on technology management was determined using the ANP technique and Super Decisions software. 
The theoretical model of research is illustrated in Figure 1, which is obtained after reviewing the previous literature, conducted researches, and also the opinions of experts.

\section{Findings Of Research First Question}

To answer the first question of research, the main questionnaire was designed that includes 51 questions (Table 1) and then the findings were analyzed using Smart PLS software in order to validate the research model. Ultimately, the research model, as shown in Figure 2, illustrates the initial structural equations model of research along with coefficients of factor loads. All the questions with a fuctor load less than 0.7 were eliminated from the research model (Hair, 2006). According to Figure 2, 15 indicators were eliminated in order to obtain a homogenous research model. 
Table 1

Influential Factors and Indicators on Technology Management

\begin{tabular}{|c|c|c|c|c|c|}
\hline Factor & Dimension & Code & Indicator & $\begin{array}{l}\text { Initial } \\
\text { path } \\
\text { coefficient }\end{array}$ & $\begin{array}{l}\text { Path } \\
\text { coefficient }\end{array}$ \\
\hline \multirow{9}{*}{$\begin{array}{l}\text { Identification } \\
\text { and } \\
\text { selection (IS) }\end{array}$} & \multirow{5}{*}{$\begin{array}{l}\text { Needs } \\
\text { identification } \\
\text { (IN) }\end{array}$} & IN1 & $\begin{array}{l}\text { Identification of needed } \\
\text { technologies }\end{array}$ & 0.967 & 0.967 \\
\hline & & IN2 & $\begin{array}{l}\text { Evaluation of technological } \\
\text { power }\end{array}$ & -0.206 & Eliminated \\
\hline & & IN3 & $\begin{array}{l}\text { Analyzing the technology } \\
\text { lifecycle }\end{array}$ & 0.730 & 0.730 \\
\hline & & IN4 & Anticipation of technology & 0.763 & 0.763 \\
\hline & & IN5 & Technology foresight & 0.722 & 0.722 \\
\hline & \multirow[t]{4}{*}{ Choice (CH) } & $\mathrm{CH} 1$ & $\begin{array}{l}\text { Identification of potential } \\
\text { resources of technology }\end{array}$ & 0.871 & 0.871 \\
\hline & & $\mathrm{CH} 2$ & $\begin{array}{l}\text { Obtaining suggested plans } \\
\text { from resources with technology }\end{array}$ & 0.777 & 0.777 \\
\hline & & $\mathrm{CH} 3$ & $\begin{array}{l}\text { Reviewing suggested plan from } \\
\text { resources with technology }\end{array}$ & 0.965 & 0.965 \\
\hline & & $\mathrm{CH} 4$ & $\begin{array}{l}\text { Identification of suitable } \\
\text { strategies for acquiring } \\
\text { technology (R\&D) or transfer of } \\
\text { technology }\end{array}$ & 0.388 & Eliminated \\
\hline \multirow[t]{7}{*}{$\begin{array}{l}\text { Acquisition } \\
\text { (AC) }\end{array}$} & \multirow[t]{3}{*}{$\begin{array}{l}\text { Negotiation } \\
\text { (DIS }\end{array}$} & D1 & $\begin{array}{l}\text { Establishing courses of general } \\
\text { negotiation }\end{array}$ & -0.158 & Eliminated \\
\hline & & D2 & $\begin{array}{l}\text { Establishing courses of the } \\
\text { specialized negotiation }\end{array}$ & 0.877 & 0.949 \\
\hline & & D3 & $\begin{array}{l}\text { Establishing courses of } \\
\text { negotiation according to the } \\
\text { method of technology } \\
\text { acquisition }\end{array}$ & 0.949 & 0.877 \\
\hline & \multirow[t]{4}{*}{$\begin{array}{l}\text { Closing the } \\
\text { contract }\end{array}$} & Co1 & $\begin{array}{l}\text { Drafting the acquisition } \\
\text { contract }\end{array}$ & 0.896 & 0.896 \\
\hline & & $\mathrm{CO} 2$ & $\begin{array}{l}\text { To simulate the negotiation } \\
\text { session for the acquisition } \\
\text { phase }\end{array}$ & 0.726 & 0.726 \\
\hline & & $\mathrm{cO3}$ & $\begin{array}{l}\text { Drafting the technical } \\
\text { appendixes }\end{array}$ & 0.804 & 0.804 \\
\hline & & $\mathrm{CO} 4$ & $\begin{array}{l}\text { Determining the acquisition } \\
\text { schedule }\end{array}$ & 0.365 & Eliminated \\
\hline
\end{tabular}




\begin{tabular}{|c|c|c|c|c|c|}
\hline Factor & Dimension & Code & Indicator & $\begin{array}{l}\text { Initial } \\
\text { path } \\
\text { coefficient }\end{array}$ & $\begin{array}{l}\text { Path } \\
\text { coefficient }\end{array}$ \\
\hline & & CO5 & $\begin{array}{l}\text { To clearly explain the } \\
\text { commitments of parties to the } \\
\text { contract }\end{array}$ & 0.731 & 0.731 \\
\hline \multirow{11}{*}{$\begin{array}{l}\text { Utilization } \\
\text { UT }\end{array}$} & \multirow{5}{*}{$\begin{array}{l}\text { Infrastructure } \\
\text { SUB }\end{array}$} & SU1 & $\begin{array}{l}\text { Determining the project } \\
\text { manager }\end{array}$ & 0.396 & Eliminated \\
\hline & & SU2 & $\begin{array}{l}\text { Providing technical } \\
\text { infrastructure and equipment }\end{array}$ & 0.712 & 0.712 \\
\hline & & SU3 & $\begin{array}{l}\text { Providing systemic and } \\
\text { informational infrastructure }\end{array}$ & 0.779 & 0.779 \\
\hline & & SU4 & $\begin{array}{l}\text { Designing and preparing the } \\
\text { processes }\end{array}$ & 0.871 & 0.871 \\
\hline & & SU5 & Planning for supply network & 0.973 & 0.973 \\
\hline & \multirow{6}{*}{$\begin{array}{l}\text { Employment } \\
\text { DEP }\end{array}$} & DE1 & $\begin{array}{l}\text { Deploying and employing } \\
\text { designed systems }\end{array}$ & 0.335 & Eliminated \\
\hline & & DE2 & $\begin{array}{l}\text { To employ experimentally and } \\
\text { determine bottlenecks }\end{array}$ & 0.986 & 0.986 \\
\hline & & DE3 & Semi-mass production & 0.281 & Eliminated \\
\hline & & DE4 & Mass (industrial) production & 0.722 & 0.722 \\
\hline & & DE5 & Propagation of technology & 0.866 & 0.866 \\
\hline & & DE6 & $\begin{array}{l}\text { Documenting the process of } \\
\text { utilization }\end{array}$ & 0.718 & 0.733 \\
\hline \multirow{7}{*}{$\begin{array}{l}\text { Development } \\
\text { and } \\
\text { improvement }\end{array}$} & \multirow{4}{*}{$\begin{array}{l}\text { Promoting } \\
\text { the } \\
\text { technology } \\
\text { level POT }\end{array}$} & PT1 & $\begin{array}{l}\text { Long term strategic program in } \\
\text { order to develop technology }\end{array}$ & 0.733 & 0.758 \\
\hline & & PT2 & $\begin{array}{l}\text { Utilizing the feedback from } \\
\text { customers }\end{array}$ & 0.758 & 0.863 \\
\hline & & PT3 & $\begin{array}{l}\text { Development of technology } \\
\text { management process in } \\
\text { business }\end{array}$ & -0.051 & Eliminated \\
\hline & & PT4 & Documenting the technology & 0.373 & Eliminated \\
\hline & \multirow{3}{*}{$\begin{array}{l}\text { Development } \\
\text { of new } \\
\text { products }\end{array}$} & DP1 & $\begin{array}{l}\text { Creation of innovation in } \\
\text { product }\end{array}$ & 0.863 & 0.717 \\
\hline & & DP2 & $\begin{array}{l}\text { Commercialization of improved } \\
\text { product }\end{array}$ & 0.717 & 0.731 \\
\hline & & DP3 & $\begin{array}{l}\text { Developing the product power/ } \\
\text { potency }\end{array}$ & -0.218 & Eliminated \\
\hline
\end{tabular}




\begin{tabular}{|c|c|c|c|c|c|}
\hline Factor & Dimension & Code & Indicator & $\begin{array}{l}\text { Initial } \\
\text { path } \\
\text { coefficient }\end{array}$ & $\begin{array}{l}\text { Path } \\
\text { coefficient }\end{array}$ \\
\hline & & DP4 & Differentiation & 0.725 & 0.725 \\
\hline & & DP5 & $\begin{array}{l}\text { Documenting the information } \\
\text { of new products development }\end{array}$ & 0.394 & Eliminated \\
\hline \multirow{10}{*}{$\begin{array}{l}\text { Propagation } \\
\text { DIF } \\
\text { Propagation } \\
\text { DIF }\end{array}$} & \multirow[t]{4}{*}{ General } & GE1 & $\begin{array}{l}\text { Propagation of technology at } \\
\text { an }\end{array}$ & 0.854 & 0.854 \\
\hline & & & organizational level & & \\
\hline & & GE2 & $\begin{array}{l}\text { Propagation of technology } \\
\text { through exhibitions }\end{array}$ & 0.701 & 0.701 \\
\hline & & GE3 & $\begin{array}{l}\text { Propagation of technology } \\
\text { through social media }\end{array}$ & 0.335 & Eliminated \\
\hline & \multirow{6}{*}{$\begin{array}{l}\text { Private PV } \\
\text { General }\end{array}$} & PR1 & Propagation of new & 0.158 & Eliminated \\
\hline & & & $\begin{array}{l}\text { products among customers } \\
\text { and } \\
\text { consumers(commercialization) }\end{array}$ & & \\
\hline & & PR2 & $\begin{array}{l}\text { Presenting the results obtained } \\
\text { from the technology to other } \\
\text { rings of supply chain }\end{array}$ & 0.982 & 0.982 \\
\hline & & PR3 & $\begin{array}{l}\text { Propagation of technology to } \\
\text { other firms according to an } \\
\text { official contract }\end{array}$ & 0.784 & 0.784 \\
\hline & & PR4 & $\begin{array}{l}\text { Propagation of technology to } \\
\text { other countries according to an } \\
\text { official contract }\end{array}$ & 0.933 & 0.933 \\
\hline & & GE1 & $\begin{array}{l}\text { Propagation of technology at } \\
\text { an organizational level }\end{array}$ & 0.854 & 0.854 \\
\hline \multirow[t]{5}{*}{ Protection } & \multirow[t]{4}{*}{ Software } & S01 & $\begin{array}{l}\text { Determining the levels of } \\
\text { access to technological } \\
\text { knowledge }\end{array}$ & 0.785 & 0.785 \\
\hline & & SO2 & $\begin{array}{l}\text { Coding of technological } \\
\text { knowledge }\end{array}$ & 0.005 & Eliminated \\
\hline & & s03 & $\begin{array}{l}\text { Official registration of } \\
\text { technological innovations }\end{array}$ & 0.865 & 0.865 \\
\hline & & SO4 & $\begin{array}{l}\text { Utilizing information security } \\
\text { management systems }\end{array}$ & 0.929 & 0.929 \\
\hline & Hardware & $\mathrm{H} 1$ & $\begin{array}{l}\text { Using suitable physical } \\
\text { equipment in order to protect } \\
\text { the technology }\end{array}$ & 0.724 & 0.724 \\
\hline
\end{tabular}




\begin{tabular}{|c|c|c|c|c|c|}
\hline Factor & Dimension & Code & Indicator & $\begin{array}{l}\text { Initial } \\
\text { path } \\
\text { coefficient }\end{array}$ & $\begin{array}{l}\text { Path } \\
\text { coefficient }\end{array}$ \\
\hline & & $\mathrm{H} 2$ & $\begin{array}{l}\text { Preparing all the supplies and } \\
\text { suitable equipment in order to } \\
\text { protect gathered knowledge }\end{array}$ & 0.029 & Eliminated \\
\hline & & $\mathrm{H} 3$ & $\begin{array}{l}\text { Using high security network } \\
\text { infrastructures }\end{array}$ & 0.773 & 0.773 \\
\hline
\end{tabular}

Findings of model tests, including reflective measurement models, structural models, and general models, are presented in Table 2. Ultimately, Figure 3 illustrates the structural model when the path coefficients are estimated and Figure 4 shows the structural model when path coefficients are significant. 
Table 2

- Results obtained from research model fitness tests

\begin{tabular}{|c|c|c|c|c|c|}
\hline Test Result & $\begin{array}{l}\text { Acceptance } \\
\text { Criteria }\end{array}$ & \multicolumn{3}{|l|}{ Type of the Test } & Model \\
\hline $\begin{array}{l}\text { Eliminating } \\
15 \text { indicators } \\
\text { with a load } \\
\text { factor less } \\
\text { than } 0.7\end{array}$ & $\begin{array}{l}\text { Load factors of } \\
\text { all indicators are } \\
\text { bigger than } 0.7 .\end{array}$ & \multicolumn{3}{|l|}{ Homogeneity test } & $\begin{array}{l}\text { Analysis of } \\
\text { reflective } \\
\text { measurement } \\
\text { model }\end{array}$ \\
\hline $\begin{array}{l}\text { Approved for } \\
\text { all factors }\end{array}$ & Bigger than 0.7 & \multicolumn{2}{|l|}{ Cronbach's alpha } & $\begin{array}{l}\text { Reliability } \\
\text { test }\end{array}$ & \\
\hline $\begin{array}{l}\text { Approved for } \\
\text { all factors }\end{array}$ & Bigger than 0.7 & \multicolumn{2}{|l|}{ Composite reliability } & & \\
\hline $\begin{array}{l}\text { Approved for } \\
\text { all factors }\end{array}$ & Bigger than 0.5 & \multicolumn{2}{|l|}{ Collective reliability } & & \\
\hline $\begin{array}{l}\text { Approved for } \\
\text { all indicators }\end{array}$ & $\begin{array}{l}\text { T-value is bigger } \\
\text { than the absolute } \\
\text { value of } 1.96 \text {. }\end{array}$ & Significance & \multirow[t]{4}{*}{$\begin{array}{l}\text { Convergent } \\
\text { validity }\end{array}$} & \multirow[t]{6}{*}{$\begin{array}{l}\text { Validity } \\
\text { test }\end{array}$} & \\
\hline $\begin{array}{l}\text { Approved for } \\
\text { all indicators }\end{array}$ & $\begin{array}{l}\text { After the fitting, } \\
\text { all the factor } \\
\text { loads are bigger } \\
\text { than } 0.7 \text {. }\end{array}$ & Homogeneity & & & \\
\hline $\begin{array}{l}\text { Approved for } \\
\text { all factors }\end{array}$ & Bigger than 0.5 & AVE & & & \\
\hline $\begin{array}{l}\text { Approved for } \\
\text { all factors }\end{array}$ & $\begin{array}{l}\text { The value of } \\
\text { collective } \\
\text { reliability is } \\
\text { bigger than AVE } \\
\text { for all factors. }\end{array}$ & CR>AVE & & & \\
\hline $\begin{array}{l}\text { Approved for } \\
\text { all indicators }\end{array}$ & $\begin{array}{l}\text { The factor load } \\
\text { of all observable } \\
\text { variables has } \\
\text { been more than } \\
\text { at least } 0.1 \text { over } \\
\text { its equivalent } \\
\text { latent variable. }\end{array}$ & $\begin{array}{l}\text { Testing } \\
\text { transverse loads }\end{array}$ & \multirow[t]{2}{*}{$\begin{array}{l}\text { Discriminant } \\
\text { validity }\end{array}$} & & \\
\hline $\begin{array}{l}\text { Approved for } \\
\text { all factors }\end{array}$ & $\begin{array}{l}\text { For each factor, } \\
\text { the square root } \\
\text { of AVE has more } \\
\text { than the } \\
\text { correlation of } \\
\text { that factor with } \\
\text { reflective } \\
\text { variables in the } \\
\text { model. }\end{array}$ & $\begin{array}{l}\text { Fornell and } \\
\text { Larcker Criterion }\end{array}$ & & & \\
\hline
\end{tabular}

Model

Analysis of reflective measurement model

Approved for Bigger than $0.7 \quad$ Composite reliability

all factors

Approved for Bigger than $0.5 \quad$ Collective reliability

Approved for

T-value is bigger than the absolute

Convergent

model

loads are bigger

than 0.7 .

Approved for Bigger than 0.5 AVE

Approved for The value of $\quad$ CR>AVE

all factors collective

bigger than AVE

for all factors.

Approved for

Testing

Discriminant

variables has

been more than

at least 0.1 over

its equivalent

Approved for

For each factor,

Fornell and

of AVE has more

than the

that factor with

reflective

variables in the model. 


\begin{tabular}{|c|c|c|c|}
\hline Test Result & $\begin{array}{l}\text { Acceptance } \\
\text { Criteria }\end{array}$ & Type of the Test & Model \\
\hline $\begin{array}{l}\text { Measurement } \\
\text { model of the } \\
\text { factors, } \\
\text { namely CON, } \\
\text { DEP, HARD, IN, } \\
\text { and SUB has } \\
\text { the average } \\
\text { quality and } \\
\text { other } \\
\text { variables } \\
\text { have strong } \\
\text { quality. }\end{array}$ & $\begin{array}{l}\text { Coefficient of } \\
\text { variation of } \\
\text { collective/shared } \\
\text { indicator with } \\
\text { three values: } \\
0.02 \text { (weak), } 0.15 \\
\text { (average), and } \\
0.35 \text { (strong) }\end{array}$ & $\begin{array}{l}\text { Testing the } \\
\text { quality of } \\
\text { measurement } \\
\text { model }\end{array}$ & \\
\hline $\begin{array}{l}\text { Approved for } \\
\text { all research } \\
\text { connections }\end{array}$ & $\begin{array}{l}\text { For all the } \\
\text { connections } \\
\text { between } \\
\text { independent and } \\
\text { dependent } \\
\text { variables, T-value } \\
\text { is bigger than the } \\
\text { absolute value of } \\
1.96 \text {. }\end{array}$ & Coefficient of significance & $\begin{array}{l}\text { Analysis of } \\
\text { structural } \\
\text { model }\end{array}$ \\
\hline $\begin{array}{l}\text { The } \\
\text { coefficient of } \\
\text { determination } \\
\text { was obtained } \\
\text { to be average } \\
\text { for factors } \\
\text { MOT and D\&I } \\
\text { factors, } \\
\text { however } \\
\text { strong for } \\
\text { other factors. }\end{array}$ & $\begin{array}{l}\text { Values of } \\
\text { coefficient of } \\
\text { determination: } \\
0.67 \text { (strong), } \\
0.33 \text { (average), } \\
\text { and } 0.19 \text { (weak) }\end{array}$ & coefficient of determination (R2) & \\
\hline $\begin{array}{l}\text { For all the } \\
\text { factors, the } \\
\text { strong } \\
\text { anticipation } \\
\text { power of the } \\
\text { model is } \\
\text { approved. }\end{array}$ & $\begin{array}{l}\text { The value of Q2 } \\
\text { with anticipation } \\
\text { power: } 0.35 \\
\text { (strong), } 0.15 \\
\text { (average), and } \\
0.02 \text { (weak) }\end{array}$ & Anticipation connection (Q2) & \\
\hline $\begin{array}{l}\text { The suitable } \\
\text { goodness of } \\
\text { fit (GOF=0.7) } \\
\text { of the general } \\
\text { model is } \\
\text { approved. }\end{array}$ & $\begin{array}{l}\text { The value of this } \\
\text { indicator: } 0.35 \\
\text { (strong), } 0.15 \\
\text { (average), and } \\
0.02 \text { (weak) }\end{array}$ & GOF & $\begin{array}{l}\text { Analysis of } \\
\text { general } \\
\text { model }\end{array}$ \\
\hline
\end{tabular}

Ultimately, the research model obtained as shown in figure 6 
Next, network analytical process (ANP) and Super Decisions software were utilized as follows in order to determine the order of factors:

\section{A) Network analytical process (ANP) and its process}

Super Decisions software was utilized in order to analyze the model and determine the order of factors and indicators under study, which in fact executes the three steps of network analytical process and model analysis in a software setting.

\section{Step 1 - Defining the model structure and forming an analysis network}

In this step, the main clusters of the model are formed using a conceptual model of research and its objectives. In each cluster, there are sets of indicators that are connected as a node and also, linked to other nodes in other clusters. Figure 7 illustrates the network structure of ANP and the type of connection between elements using Super Decisions software.

\section{Step 2 - Pairwise comparisons and allocating weight to the indicators of the ANP model}

ANA control hierarchy is a set of indicators utilized to compare the interactions that might exist within the network. A numerical range of 1 to 9 has been considered in order to allocate weights to the criteria in the ANP model. According to this method, the network will be divided into smaller branches and each pairwise comparison is established for each element per branch, such as $\mathrm{J}$, relative to another element in the branch $\mathrm{J}$.

\section{Step 3 - Forming super weight matrix according to the data}

According to the pairwise comparison conducted in the previous step, a super weight matrix is established and the weight of each criterion and indicator is defined and determined based on the vector system. In other words, each column of the super matrix consists of several specific vectors that determine the total of relative weight vectors of criteria and indicators.

\section{B) Determining the order and significance of criteria in comparison to other elements}

Each group in the model has its own specific results. As a result of extensive research results, some of the most important and major conditions obtained from executing ANP are mentioned in this section. The results of indicators weight, which are obtained using Supers Decisions software, are illustrated in Table 3.

Table 3 - Determining the order of influential indicators on designing technology 
management using ABP method

\begin{tabular}{|lll|}
\hline Name of factor or element & Calculated weights & Normalized weights \\
\hline Propagation & 0.041610 & 0.208052 \\
\hline Acquisition & 0.040393 & 0.201968 \\
\hline Utilization & 0.028149 & 0.140745 \\
\hline Development and improvement & 0.035211 & 0.176054 \\
\hline Protection & 0.023323 & 0.116614 \\
\hline Identification and selection & 0.031314 & 0.156568 \\
\hline
\end{tabular}

According to the output of the super decisions program, the order of technology management factors is obtained using the ANP method as shown in Diagram 1.

According to the data of questionnaires and output obtained from PLS software significant coefficients and as it can be seen in Table 4, all coefficients of significance between the factors are bigger than the absolute value of 1.96 , and this illustrates that all factors of technology management with a level of significance (95\%) have been approved.

Table 4

Coefficient of the significance of technology management factors

\begin{tabular}{|llll|}
\hline Factors & sign & Significance & Assumption test result \\
\hline Identification and selection & IS & 2.800 & Approved \\
IS--MOT & & & \\
\hline Acquisition AC--MOT & AC & 6.607 & Approved \\
\hline Utilization UT---MOT & UT & 2.058 & Approved \\
\hline Development and improvement D\&I---MOT & D\&I & 3.595 & Approved \\
\hline Propagation DIF--MOT & DIF & 4.405 & Approved \\
\hline Protection PRO--MOT & PRO & 2.156 & Approved \\
\hline
\end{tabular}

Discussion \& Conclusion

This research has been conducted in order to identify and determine the order of influential factors on technology management in MAPNA Group. The designed model in this research can be utilized in power plant industries in order to identify and determine the order of influential factors on technology 
management. In this research, 51 indicators were identified and then, categorized into 6 factors and 12 dimensions and the research results illustrated that factors, namely acquisition, identification, utilization, education, protection, and selection have a significant impact on technology management. Among these 6 factors, the "acquisition" factor has the highest impact on the technology management. Propagation is the second influential factor and the following factors are placed in the next orders: development and improvements, identification and selection, protection, and utilization. According to the results obtained from Smart PLS software, indicators with the highest $\mathrm{r}^{2}$ account for the highest share in explaining variance, improvement, and anticipation of related factors behavior. Therefore, these matters should be focused on more.

According to the results, the following suggestions are presented:

Related to the "identification and selection" factor, the indicator "identification of needed technologies" (IN1) has the highest $\mathrm{r}^{2}$, meaning that it accounts for the highest share in explaining the variance of identification and selection factor. Hence, companies are recommended to establish courses and form teams in order to scout the technology. Related to the "acquisition" factor, on the other hand, the indicator "drafting the technical appendixes" (CO3) has the highest $\mathrm{r}^{2}$, and hence, companies are recommended to be inspired by technical appendixes of other projects in order to promote this indicator. Related to the "utilization" factor, the indicator "planning for supply network" (SU5) also accounts for the most share in explaining this factor, and hence, companies are recommended to deploy a system in order to identify and evaluate the suppliers in order to promote this indicator. Related to the "development and improvement" factor, the indicator "commercialization of improved product" (DP2) has the highest $\mathrm{r}^{2}$, and hence, companies are suggested to introduce newly developed products to their related companies in order to promote this indicator. On the other hand, related to the "propagation" factor", the indicator "propagation of technology at organizational level" (GE1) has the highest $\mathrm{r}^{2}$, and hence companies are suggested to propagate the technology in the form of a comprehensive plan for a certain group of staff who should be get acquainted with this technology and this will help promote this indicator.

After conducting and using pairwise comparisons, ANP technique, and Super Decision software, the results of determining the order of technology management factors are presented as follows:

First order: Propagation, Second order: Acquisition, Third order: Development and improvement, Fourth order: Identification and selection, Fifth order: Utilization, and Six order: Protection

Among these factors, the factor "propagation" was given the highest order, showing that chief managers of the company show great interest in the propagation of technology and following suggestions are presented in order to improve its indicators and dimensions: introducing the factors of company technology propagation through exhibitions and media advertisements, propagating new technologies in the form of products among customers and consumers, presenting the results obtained from the technology to other rings of the supply chain, propagating technology to other firms according to an official contract. 
The factor "acquisition" is given the second order and therefore, the following suggestion can be presented in order to improve its dimensions and indicators: increasing the number of courses of general and specialized negotiations according to the country that holds the technology, drafting the contracts, promoting the simulation of negotiation session for success in acquiring the technology, drafting the technical appendixes and determining the technology acquisition schedule.

The factor "development time improvement" was given the third order and therefore, the following suggestion can be presented in order to improve its dimensions and indicators: promoting the technology level by preparing long term technology development programs, to utilize the customers feedback in order to improve and change business process and documenting the promoted technology, developing new products and creating innovation in the products, commercializing the improved products, empowering the products, developing the product potency and products differentiation.

The fourth factor is "identification and selection" therefore, the following suggestion can be presented in order to improve its dimensions and indicators: related to the identification dimension, the technology needed by the company should be identified based on the company objectives, technological power of the company should be evaluated, anticipating the technology and technology foresight. Related to the "selection" dimension, possible sources of technology should be identified, suggested plans from these sources should be obtained and reviewed and suitable strategies to acquire technology should be identified.

The fifth factor is "utilization". Therefore, the following suggestion can be presented in order to improve its dimensions and indicators: the infrastructure of project management determination should be promoted, technical, equipment, systemic, and informational infrastructure should be provided, processes should be designed and prepared, plans should be made for supply network, deployment and utilization of the designed systems should be promoted, experimental utilization and bottlenecks should be determined, semi mass production and utilization process should be documented.

The sixth factor is "protection". Therefore, the following suggestion can be presented in order to improve its dimensions and indicators: level of access to technological knowledge should be promoted, technological knowledge should be coded, technological innovations should be officially registered, IT management system should be utilized, suitable physical equipment should be utilized, supplies and suitable equipment of protecting gathered knowledge and high-security network infrastructures should be utilized.

According to conducted researches in technology management, all six facts factors have a significant influence on technology management and hence, all six factors must be paid attention to. In case such a thing does not happen, reaching success in technology management will fail.

\section{Declarations}

Funding : no funds, grants, or other support were received during the preparation of this manuscript. 
Conflicts of interest/Competing interests: Not applicable for that section

Availability of data and material: Not applicable for that section

Code availability: Not applicable for that section

Ethics approval: Not applicable for that section

Consent to participate: Not applicable for that section

Consent for publication: Not applicable for that section

Authors' contributions: Not applicable for that section

\section{References}

1-Aboelmaged, Mohamed; "The drivers of sustainable manufacturing practices in Egyptian SMEs and their impact on competitive capabilities: A PLS-SEM model”, Journal of Cleaner Production, No. 175, pp. 207-221, 2018.

2-Ahmad, N.; Lazim Shamsuddin, H.M.; A. Wahab, E.; “The Relationship between Technological Capability and Manufacturing Performance", International Journal of Supply Chain Management, Vol. 8, No. 2, pp. 930-938, 2019.

3-André Luiz Teixeira Vinci,2016," Proposal of an Evaluation Model for Mental Health Care Networks Using Information Technologies for its Management", Procedia Computer Science 100 (100): 826-831

4- Ansari, Reza; Abedi Sharbiani, Ali Akbar; Khayat Khuzdoz, Mohammad; "Study of the effect of technology management activities on the agility capabilities of the organization" Journal of Production and Operations Management, Volume 7, Number 1, 12, pp. 214-191, 1396.

5- Arana-Solares, Iván Andrés; Ortega-Jiménez, César H.; Alfalla-Luque, Rafaela; de los Ríos, José Luis Pérez-Díez; "Contextual factors intervening in the manufacturing strategy and technology managementperformance", International Journal of Production Economics, No. 1, pp. 1-33, 2018.

6-Dilek Cetindamar, Robert Phaal, David R. Probert,2016," Technology management as a profession and the challenges ahead", Journal of Engineering and Technology Management

7- Eslami, Abolfazl and Tahmineh Nategh, 2016, The role of total quality management and technology management in determining quality and innovation performance (Case study: Tehran Automobile Manufacturing Company), 2nd International Conference on Management, Economics and Development, Tehran, Institute Scientific Kian Pajouhan

8- Estrada, Salvador; Cano, Karen; Aguirre, Joao; "How is technology managed in SMEs Differences and similarities between micro, small and medium enterprises?", Contaduríay Administración, Especial 
Innovación, Vol. 64, No. 1, pp. 1-21, 2019.

9- Faiz Abadi Maryam; Mohammad Hossein Namazi Ghadim, Mohammad Hossein Davoodabadi Farahani, 2015, "General Framework of Management in the Evolution of Technology", International Conference on Management, Economics and Industrial Engineering, Tehran, Vira Capital

10- Ghahremani Mohammad, 2015, "Study of the effect of technology management and research and development on the performance of the organization in terms of innovation and quality", the second national conference and the second international conference on management and accounting in Iran, Hamedan, Permanent Secretariat

11- Gkypali A. H.; Lee, J.; "Open Innovation Management: Chal Lenges and Prospects", International Conference on Leadership, Technology and Innovation Management, Procedia - Social and Behavioral Sciences, Vol. 41, pp. 130 - 138, 2018.

12-Günther Schuh a, Linda Kra mer,2016," Cybernetic Approach for Controlling Technology Management Activities, Laboratory for Machine Tools and Production Engineering, RWTH Universtiy Aachen, Steinbachstr. 19, 52074 Aachen, Germany

13-Hee-Woon Cheong,2016," Management of Technology Strategies Required for Major Semiconductor Manufacturer to Survive in Future Market”, Procedia Computer Science

14- Hori, Marzieh; Nikbakht, Mohammad Reza; Thank you Zareh Ahmad Reza; "Relationship between Technology Management and Operational Performance in Manufacturing Companies", Journal of Advanced Manufacturing Processes, Volume 4, Number 6, pp. 79-69, 1397.

15- Huhtala, J. P.; Sihvonen, A.; Frösén, J.; Jaakkola, M.; Tikkanen, H.; “Market orientation, innovation capability and business performance: Insights from the global financial crisis”, Baltic Journal of Management, Vol. 9, Issue 2, pp. 134-152, 2015.

16- I.A. Yanvarev, V anyashov A.D, Krupni ,kov A.V,2015," Thermal management technologies development for the gas transport on the gas- main pipeline”, International Conference on Oil and Gas Engineering

17- Noorian Seyed Hossein; Adamit Bahareh, 2016, "Effective use of technology management process, the main factor of success in information technology projects, National Conference on Computer Science and Engineering", Najafabad, Islamic Azad University, Najafabad Branch

18- Radfar, Reza; Khamseh, Abbas; Technology Management, A Comprehensive Approach to Technology, Innovation and Commercialization Second Edition, Tehran Scientific and Cultural Publications 1397.

19- Radfar, Reza, Abbas, Khamseh, 2016, "Technology Management", scientific and cultural publications 20-Safarloo Ehsan, 1394, "Technology", the first scientific conference on modern horizons 
21-Sanjay ,Kumar, Shivam Guptab, Donatella Bussoc, Shampy Kambojd," Top management knowledge value, knowledge sharing practices, open innovation and organizational performance", Journal of Business Research,2019.

22-Schuh, G.; Kramer, L.; "Cybernetic approach for controlling technology management activities”, 48th CIRP Conference on MANUFACTURING SYSTEMS - CIRP CMS 2015, Procedia CIRP 41, pp. 437 - 442, 2016

23-Shad, Muhammad Kashif; Woon, Lai Fong; Lai Fatt, Chuah; Klemeš, Jiří Jaromír; Bokhari, Awais; "Integrating Sustainability Reporting into Enterprise Risk Management and its Relationship with Business Performance: A Conceptual Framework", Journal of Cleaner Production, No. 208, pp. 415-425, 2018.

24-Tas, M.; Yeloglu, H.O.; "The need for Technology Management Education for Undergraduate Programs: A Conceptual Framework", Universal Journal of Educational Research, Vol. 6, Issue 2, pp. 249-256, 2018.

25- Vare, Ahmadreza and Mohammad Amin Hemmati, 2016, "Designing a knowledge management model for large projects with a technology management and system engineering approach in projectbased organizations (Case study: a selected organization)"

\section{Figures}




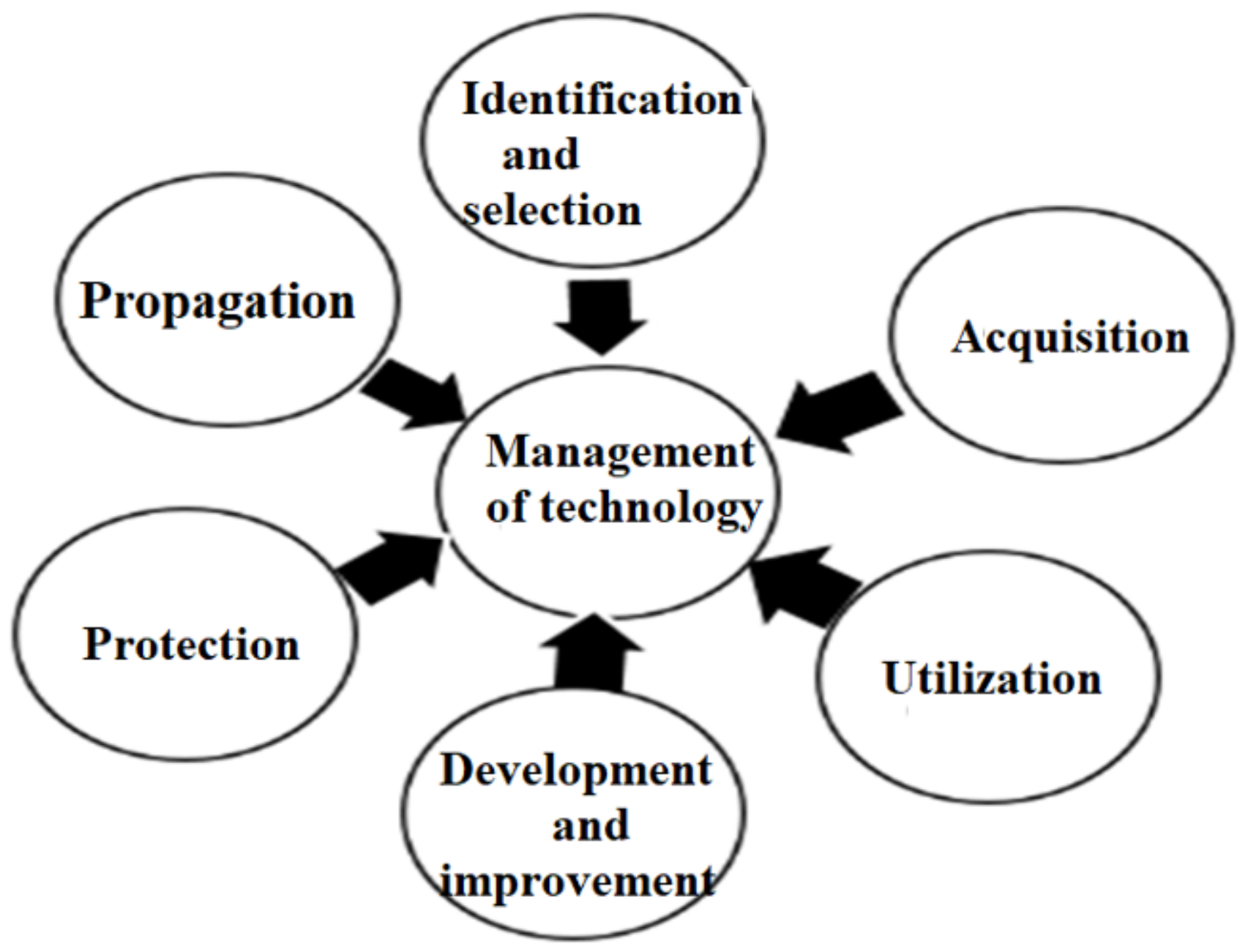

Figure 1

Theoretical model of the research 


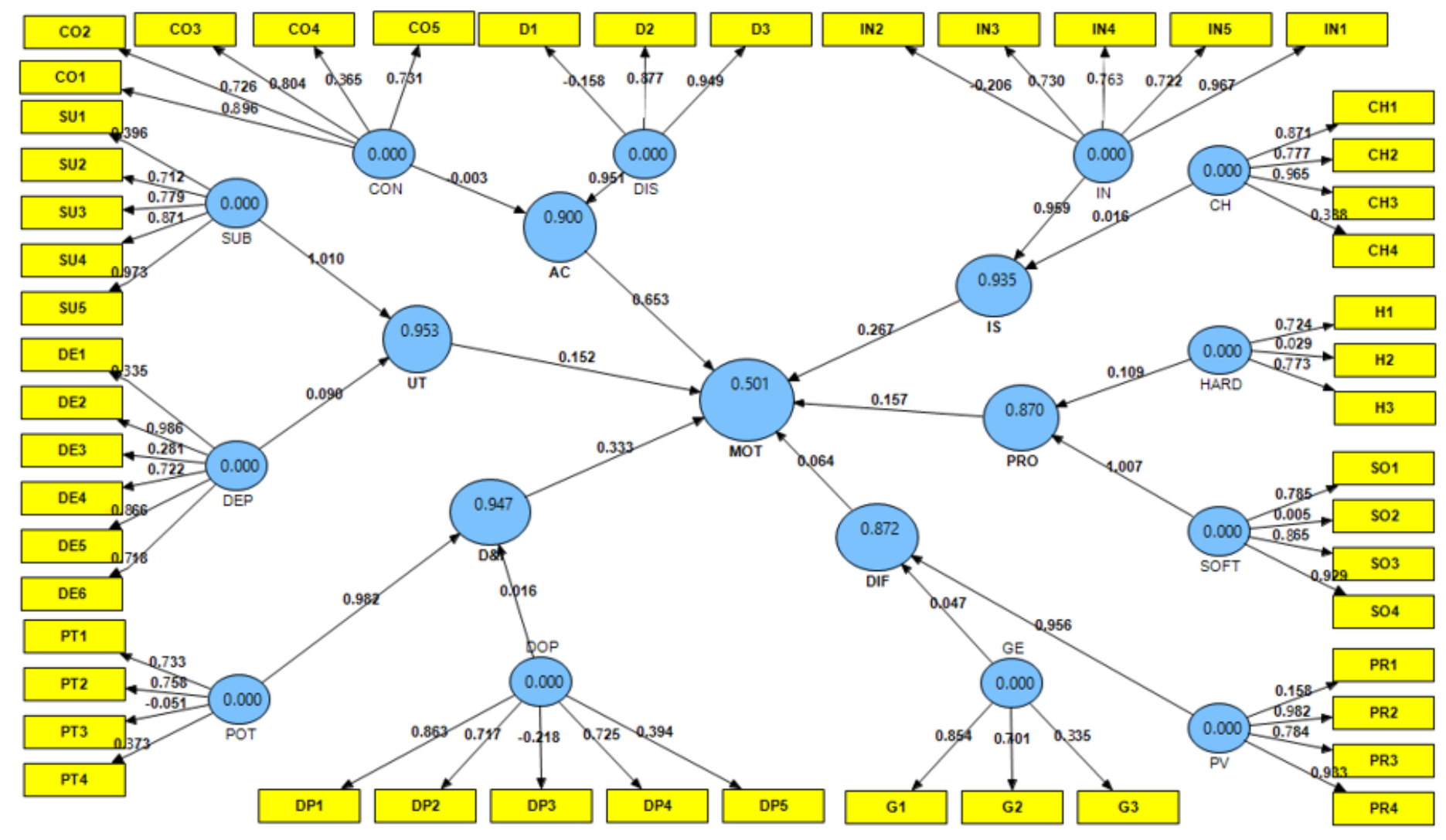

Figure 2

Initial measurement model of research along with coefficients of factor loads 


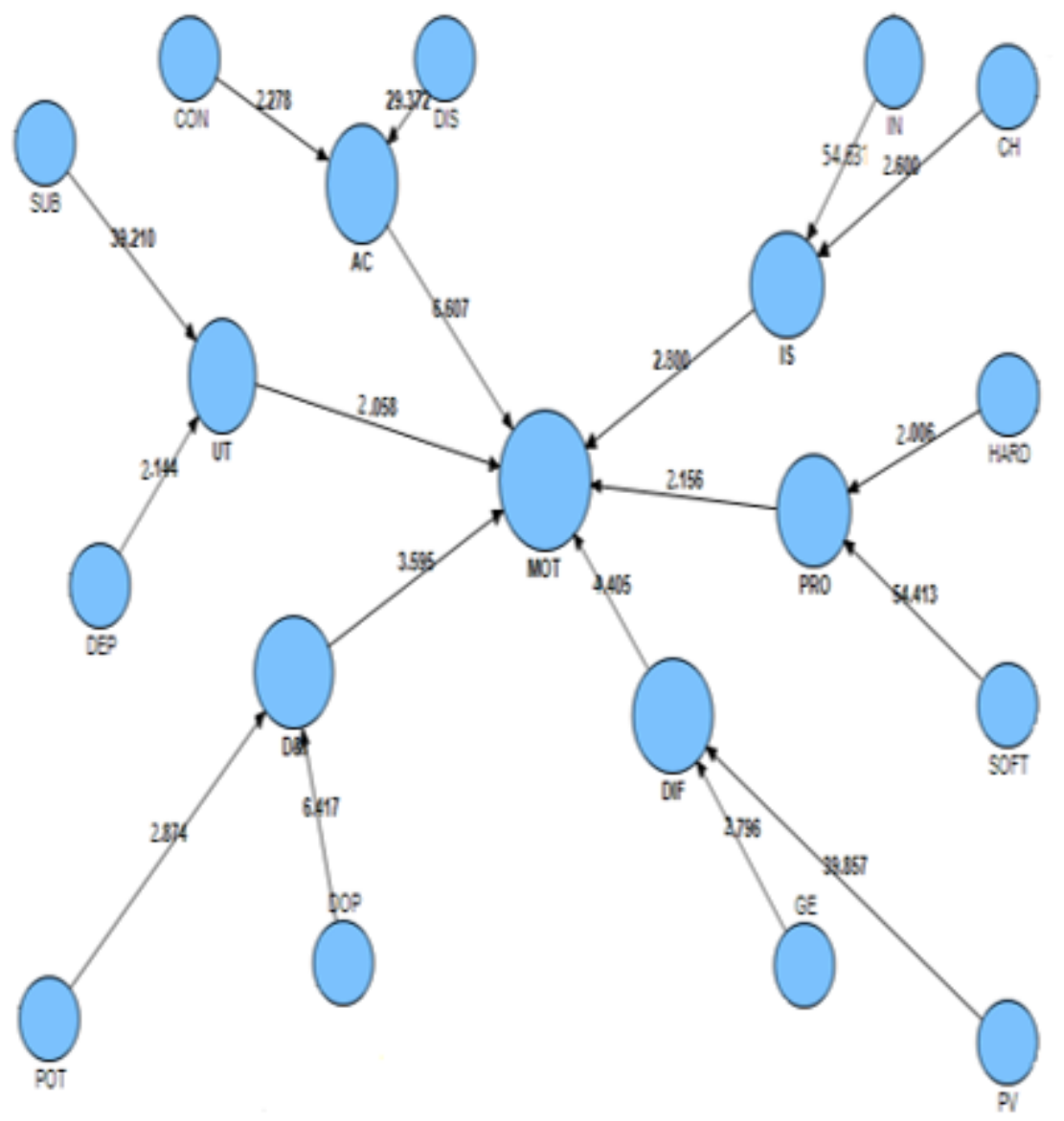

Figure 3

The structural model when the path coefficients are estimated (standard) 


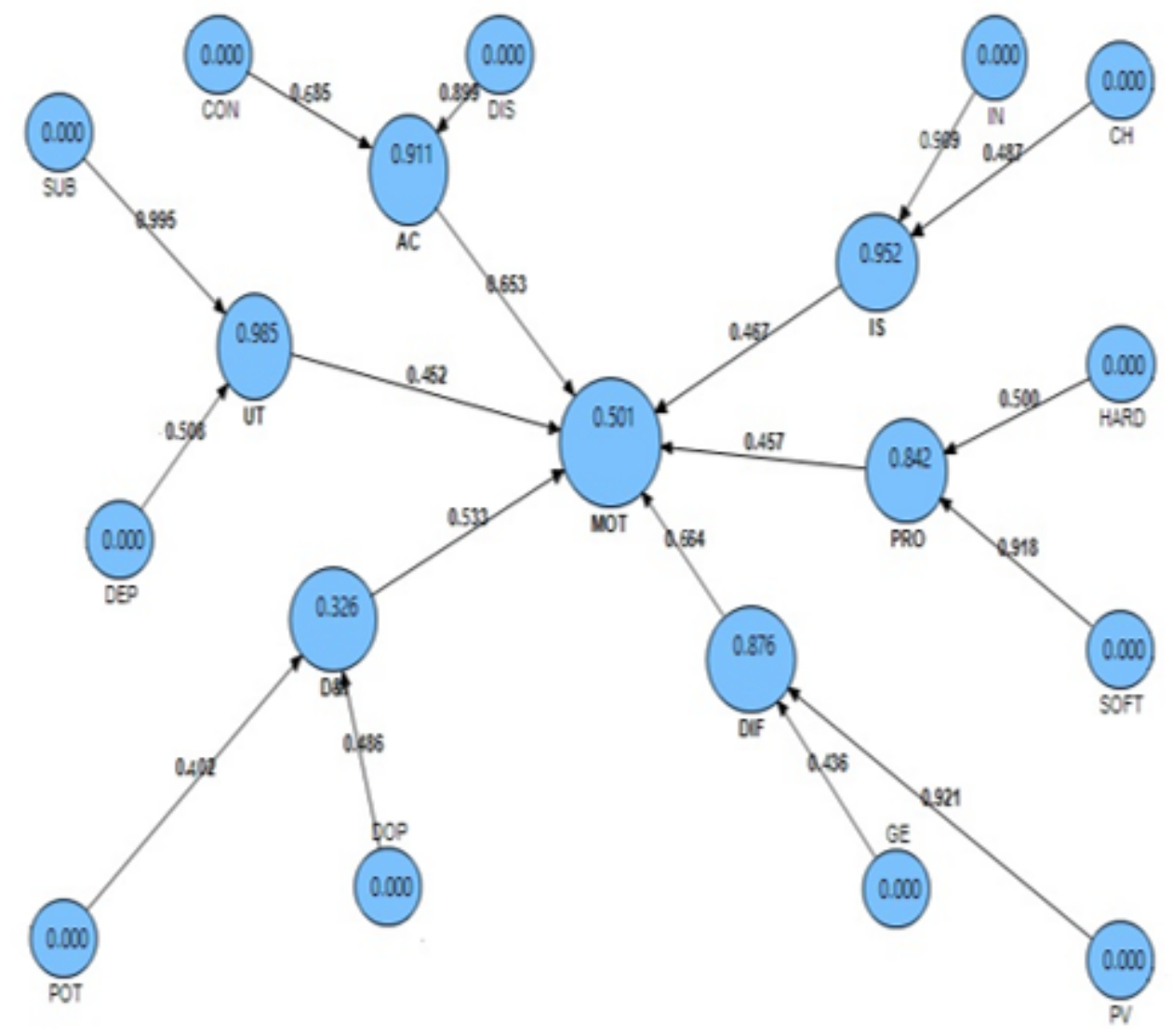

Figure 4

The structural model when path coefficients are significant

\section{Image not available with this version}

Figure 5

Caption not included with this version. 


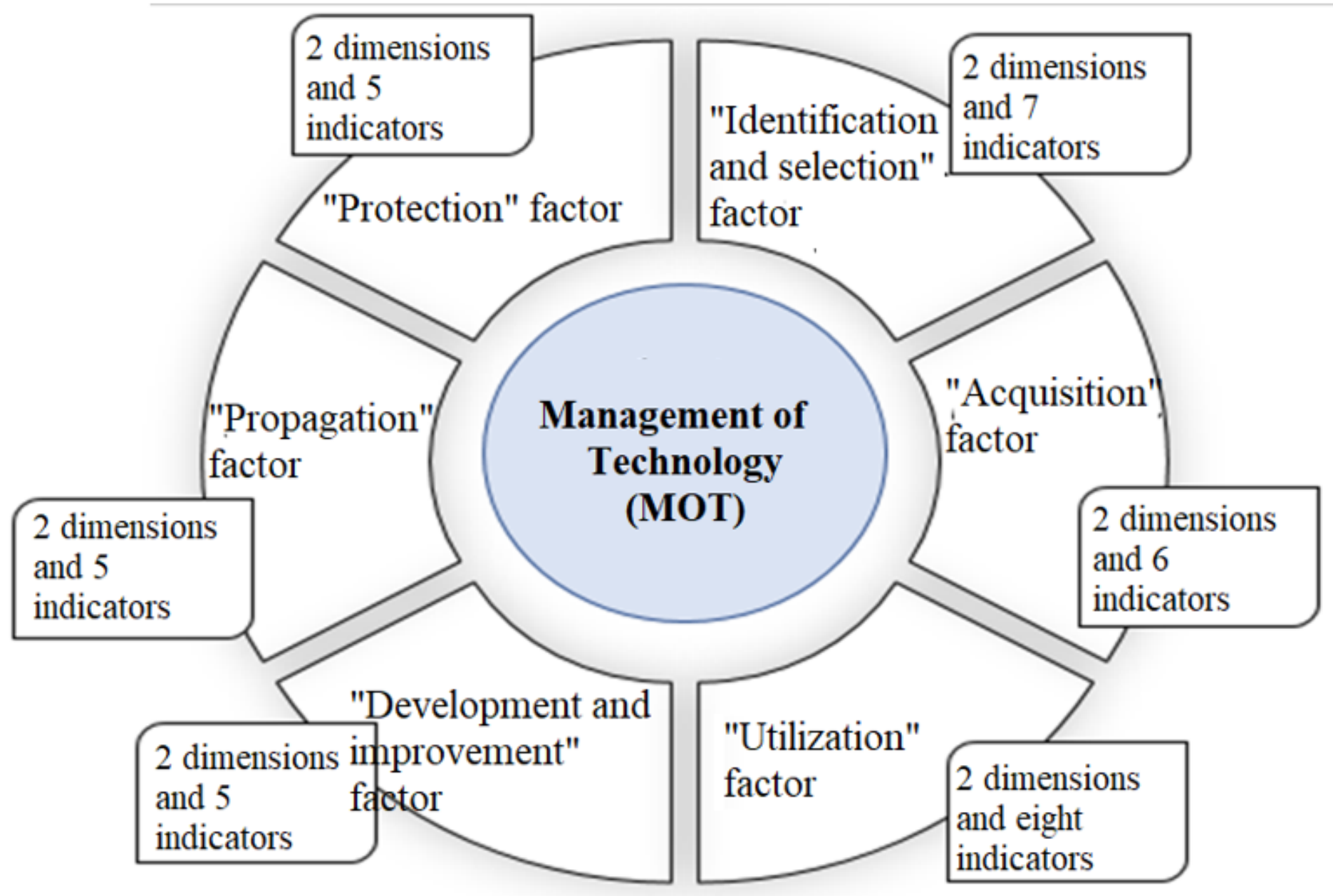

Figure 6

Technology management model 

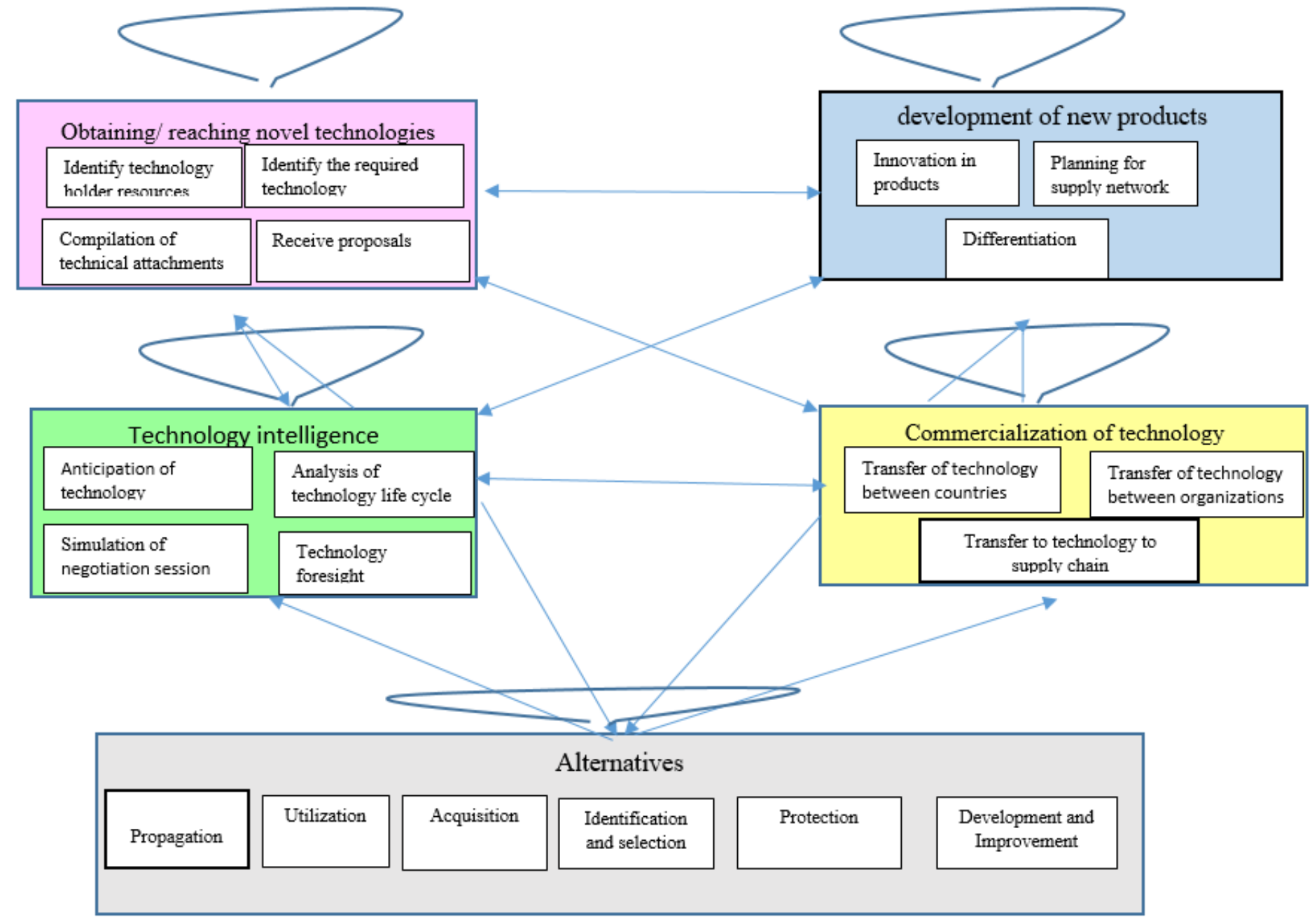

Figure 7

ANP network in order to determine the factors of technology management

\begin{tabular}{|c|c|c|c|c|}
\hline Name & Graphic & Ideals & Normals & Raw \\
\hline Propagation & & 1.000000 & 0.208052 & 0.041610 \\
\hline Acquisition & & 0.970757 & 0.201968 & 0.040393 \\
\hline Utilization & & 0.676492 & 0.140745 & 0.028149 \\
\hline Development and impro & vement & 0.846201 & 0.176054 & 0.035211 \\
\hline Protection & & 0.560505 & 0.116614 & 0.023323 \\
\hline Identification as selecti & & 0.752544 & 0.156568 & 0.031314 \\
\hline
\end{tabular}

Figure 8 
Diagram 1 - Determining the order of influential factors on technology management 